\title{
DEVELOPMENT OF PASSING LEARNING MODEL ON VOLYBALL FOR CLASS VIII SMP STUDENTS
}

\author{
Rini Yatulkhusna ${ }^{1}$, Safaruddin $^{2}$, Meirizal Usra $^{3}$, Iyakrus $^{4}$, Herri Yusfi $^{5}$ \\ Program Studi Magister Pendidikan Olahraga, FKIP, \\ Universitas Sriwijaya ${ }^{1,2,3,4}$ \\ theyovu@gmail.com
}

\begin{abstract}
This study aims to develop a learning model of volleyball passing over for class VIII junior high school students. The research method used is research and development (research and development). The subjects in this study were eighth grade students of SMP Negeri 29 Palembang. The small group test consists of 10 students and the large group test consists of 20 students. The technique of taking the research subject used a purpose sampling technique. The results showed that the development of the volleyball passing over learning model had a material expert validity percentage level of $98 \%$, and linguist validity $96 \%$, so that the development of a volleyball passing over learning model could be said to be feasible. The level of reliability in the small group trial is 0.988 and the large group trial is 0.996, so it can be categorized as a high level of reliability. Overall, it is stated that the development of the volleyball passing learning model for class VIII students is very helpful for students in learning passing over more effectively.
\end{abstract}

Keywords: volleyball, learning model, top passing

Correspondence author: Rini Yatulkhusna, Program Studi Magister Pendidikan Olahraga, FKIP, Universitas Sriwijaya, Indonesia. E-mail : theyovu@gmail.com

DOI http://dx.doi.org/10.31851/hon.v5i1.6029

\section{(i) (2)}

Jurnal Halaman Olahraga Nusantara licensed under a Creative Commons Attribution-ShareAlike 4.0 International License

\section{INTRODUCTION}

Renewal in life goes hand in hand with the development of an increasingly modern era, not least in the world of education. Human readiness when time has run out by the times to face various difficulties that will arise in the future. Resilience in the face of the times must begin to be applied from now on. In an increasingly advanced world of education requires the support of the changing factors of the times. 
In the development of personality in the world of education, it is seen in the realization of individual potential and this can be taken as a provision in the future. To achieve individual goals in achieving education, innovation in education is needed, especially in learning activities that are always increasing in quality. Likewise with improving the quality of physical education. Samsudin stated that "physical education is a learning process through physical activities designed to improve physical fitness, develop motor skills, knowledge and behavior of healthy and active living, sportsmanship, and emotional intelligence"

Physical education certainly has educational goals to be achieved. In Law No. RI. 3 of 2005 article 1 paragraph 11 concerning the National Sports System formulated that "sports education is physical education and sports carried out as part of a regular and continuous educational process to acquire knowledge, personality, skills, health, and physical fitness".

The curriculum for junior high school with the 2013 curriculum in its basic competence states practicing variations and combinations of basic techniques of various forms of big ball games with good coordination. Within the scope of the big ball game there is volleyball with various basic techniques. such as serve, passing down, passing up, and smash. Upper passing is a way of playing the ball above the front of the forehead using both fingers, especially the tips of the thumb, index, and middle fingers while the other finger tips help hold the ball. This is what gives students anxiety to participate in over-the-top learning activities well, while volleyball is a sport that is liked and favored by junior high school students because the development of basic technical skills has begun to be seen and in volleyball games where they can do it fun and learn how to play fair play.

This is actually a very good start in learning, when students have a great will, the transfer of knowledge can be more effective, but volleyball learning can be less effective and fun, even making children find it difficult to do this learning due to the lack of teacher creativity. in making models that are attractive to students 
but still effective in achieving the goals designed in each lesson.

Jim Lavin stated "Every child is capable of being creative. However, when pupils are forced to suppress their creativity by participating in an activity they dislike or which does not motivate them, then their response can lead to inappropriate behavior". The statement explains that every child has the ability to develop creativity, but when children are forced to emphasize their creativity by participating in an activity that they do not like or that do not motivate them, creativity is difficult to generate. In this case, the teacher factor is very important in the self-development of a student.

In volleyball learning, if a teacher is lacking in developing creativity, students lack interest in participating in learning, especially for students who have experienced trauma injuries. For this reason, a teacher must be able to carry out tasks and adopt new learning models that can help students' problems and achieve educational goals, especially in passing over material. This is sometimes difficult for teachers to realize. Weaknesses in physical education often occur in the development of monotonous models that often make students feel bored in following physical education subjects, this is still a lot of teachers who use physical learning styles by emphasizing "teacher centered" children lack the freedom to perform movement skills to the fullest. This is what happened to students in one of the Palembang City Junior High Schools, the teacher had not used the learning model and had not optimized the creativity of the teacher so that students in participating in physical education learning experienced boredom, therefore students chose to play with their peers so that the material used was delivered by the teacher is not maximally achieved by students.

Student interest is still low in volleyball learning activities, especially passing over so that the results obtained are less than optimal. Therefore, to overcome this problem there must be an effort to overcome it, namely by using model development. The researcher used to convey the material for passing over with models that were more interesting and fun for class VIII students. Therefore, 
researchers prefer to develop a model of passing over at the junior high school level that is adapted to the characteristics of students. Volleyball learning for class VIII students has reached the development of skills, so in learning later the children will do the over-passing model in passing learning.

Through the development of the above-passing model, it is hoped that it can help students learn better upper-passing skills. And it can be used as a challenge for physical education teachers, especially when providing material for passing over through the development of a model for passing over so that students can pay attention enthusiastically and feel happy without being bored when following it. In order to achieve this goal, a teacher must also pay attention to the characteristics of children at the age of class VIII students in general who like to play, love to move, like to work in groups and like to feel or do something directly. So that later in using these models the teacher can align with the conditions and situations faced by students. Making the right development model in the upper passing material which of course the movement must support and relate to the upper passing (beginning, hitting, and follow-up movements). Related to the statements that have been stated above, it shows that it is necessary to develop a volleyball top passing model, which can later be used as a solution to facilitate students in learning top passing more effectively.

\section{METHOD}

This study uses research and development methods, research methods used to produce certain products and test the effectiveness of these products. This research was conducted at SMP Negeri 29 Palembang with a focus on class VIII students. The technique of taking the research subject used a purpose sampling technique. The research subjects consisted of 30 students of class VIIISMP Negeri 29 Palembang.

The procedure used in this research is the development of Sugiyono. Theproduct development procedure is first, Determination of Ideas Needs analysis 
collected from the results of observations, interviews and questionnaires given to teachers and students so that ideas are obtained. The results of the needs analysis obtained a conclusion whether the development of the model is needed or not for class VIII junior high school students. Second, the making of the initial product model in the form of a series of model development in the above passing material to serve as a guideline or guide to facilitate the passing over learning process so that it can obtain good learning outcomes Third, after the modeling is complete, the next step is to evaluate the model. This evaluation was carried out to improve and refine the model of passing over for grade VIII SMP students that had been made. The results of the model development were then validated by 3 volleyball experts and 1 physical education learning expert. After that, the initial product was tested in small group trials and only after that the trials were carried out in large groups to find the results.

The data that can be obtained in this study were obtained through questionnaires, observations, interviews and analysis of various types of documents. The effectiveness of this study was tested using a pre-experimental research design in the form of the one group pretest-posttest design. The instruments used in this study were questionnaires for needs analysis, expert evaluation questionnaires and model test questionnaires for students. And the data analysis technique used is a quantitative descriptive analysis technique with a percentage.

\section{RESULT AND DISCUSSION}

\section{Result}

Preliminary observations were carried out by testing the initial test which showed a significant difference in the average results between the two tests. The average result of the initial test measurement obtained a value of 49.67 and the second test obtained a value of 86.67 , so there is a difference in the average result of 37 . 
The initial product draft planning stage begins with the product design step. This product is named "Volleyball Pass Modification Guide". This product develops a volleyball passing learning model as a tool to help teachers and students learn independently and to know the correct movement.

The results of this product validation were carried out before a small-scale trial by a material expert validator represented by Mrs. Dr. Siti Ayu Risma Putri, M. Pd, the percentage of assessment results on the development of the volleyball passing over learning model for students VIII was $98 \%$ in the very good or decent category and the validator for linguistics was represented by Mrs. Susy Sepriani, M. Pd. The percentage results of the assessment of the development of the volleyball passing over learning model for students VIII are $96 \%$ with a very good or decent category.

The results of the small-scale trial show that there are 3 class VIII students who get test scores > 100 in the very good category, 1 student from class VIII who gets test scores between 90-99 in the very good category, as many as 3 students in class VIII get test scores. between 80-89 in the good category, as many as 2 students of class VIII who get test scores between 70-79 in the good category, and 1 student in class VIII who gets test scores between 60-69 in the fairly good category. While the calculation using SPSS 21 has been carried out with the number of respondents 10 students of class VIII, then the mean value is 83.00 , median is 80.00 , standard deviation is 14.181 , range is 40 , minimum value is 60 , maximum value is 100 , and sum is 830 . Results The histogram output depicts normal data with a balanced distribution of data. For the normality test obtained a value of 0.885 . So, it can be concluded that the significance value is $0.885>0.05$ which is normally distributed. Small-scale data reliability has a high and significant correlation because rcount $>$ rtable $(0.988>0.632)$. Then the results of the calculation of the Paired Sample Test for small-scale data, it is known that the value of Sig (2-tailed) is $0.000<0.005$, then Ho is rejected and $\mathrm{Ha}$ is accepted. 
The results of the large-scale trial showed that there were 6 students of class VIII who got test scores $>94$ in the very good category, as many as 8 students of class VIII who got test scores between $88-93$ in the very good category, as many as 3 students of class VIII who got test scores between 76-81 in the good category, and as many as 3 students of class VIII who got test scores between 7075 in the good category. While the SPSS 21 calculation that has been carried out with the number of respondents is 20 students of class VIII, then the mean value is 88.50 , median is 90.00 , standard deviation is 10.400 , range is 30 , minimum value is 70 , maximum value is 100 , and sum is 1770 . Histogram output results describe normal data with a balanced distribution of data. For the normality test obtained a value of 0.141 . So, it can be concluded that the significance value is $0.141>0.05$ which is normally distributed. The reliability of the data in the largescale test is highly correlated and significant because rcount > rtable (0.996> 0.444). Then the results of the calculation of the Paired Sample Test known that the value of $\mathrm{Sig}$ (2-tailed) is $0.000<0.005$, then $\mathrm{Ho}$ is rejected and $\mathrm{Ha}$ is accepted.

\section{Discussion}

This research is the development of a volleyball passing learning model for class VIII students. The product draft design stage aims to identify and determine the concept that will be used as a model for learning to pass over volleyball. This product uses a learning model as a tool to assist class VIII students in doing learning at school or learning independently which aims to find out the correct movement, in the development procedure. The correct movement can be done with repeated practice. According to Syafruddin (2013:2) "Exercise is basically a process of physical (physical) and psychic (mental) activity with certain settings (dose) of training load to achieve the desired training goals by using methods, materials or other forms of exercise that right". Exercise according to the program and designed with a structure has benefits for someone to achieve achievement. According to Iyakrus (2012: 2) Exercise aims to improve the appearance of skills, 
with the movement in the exercise can make it easier for class VIII students to practice passing over volleyball.

In addition, the movement can also be seen through the image. According to Haryanti (2018: 18) images are included in the visual media that serves to channel messages from the recipient of the source to the recipient of the message. In addition, according to Rohini (2010:79) regarding the use value of images has a number of implications for teaching, namely the use of images can stimulate students' interest or attention, images are selected and adapted appropriately, helping students understand and remember the information content of accompanying verbal materials. , and terms that are non-verbal or symbols such as arrows or other signs in the image can clarify or change the actual message.

Product validation is an activity process to assess whether the product design, in this case the new work system will rationally be more effective than the old one or not (Sugiyono 2013: 302). In order for this development research to be valid, the researcher added a questionnaire where material experts and media experts filled in according to the questions provided or in other words used content validity. Because according to Saifudin Azwar (2011: 42) content validity is validity based on expert opinion that the instrument is feasible to be used as a data collection tool. Evidence of content validity is obtained by making an agreement from experts (expert judgment), namely material experts and media experts. So that the product from the research will be validated by experts or experienced experts to assess the new products that have been designed, in order to find out the weaknesses and strengths. According to Winarno (2011: 22) states that the validity of a product can be calculated by correlating the product assessment obtained with the assessment of two or more people. Agree with Arikunto (2012:211) states that validation is a measure that shows the levels of validity or validity of an instrument. Validation is done by asking for an assessment from two experts with an assessment instrument in the form of a questionnaire. The questionnaire is said to be standard if the preparation of the test is always 
attempted so that the scoring system is very objective so that a high level of test reliability is obtained, there is always the use of a score scale and relevant norms, and detailed and standardized test implementation (Zaenul, 2008:23). And Suryabrata (2008:60) suggests that instrument validity is defined as the extent to which the instrument records or measures what is intended to be recorded or measured. Product validation was carried out by a material expert, namely Mrs. Dr. Ayu Risma Putri, M. Pd.. obtained a percentage of $98 \%$. Furthermore, the validation was carried out by a linguist, namely Mrs. Susy Sepriani, M. Pd. obtained a percentage of $96 \%$. According to Arsil (2015: 192) suggests that the very good or decent criteria in the validation process lies in the percentage range of $81-100 \%$. Based on the opinion above, it can be said that the validation results for material experts and IT experts are in the very good or decent category so that the product can be continued at the trial stage.

The product development of the volleyball passing over learning model for class VIII students has been revised. According to Sugiyono (2013: 29) states that product revisions are carried out to correct errors or deficiencies that occur during the product manufacturing process. several revisions, namely from the material aspect, the selection of models is carried out in stages, from models with low difficulty to high difficulty. In addition, the revision of the language aspect is to use sentences that are easily understood by the reader, avoid giving symbols with the same color, then remove the color and distinguish each symbol, the formation does not need to be included, if there is a clearer picture. The revisions made were aimed at facilitating the implementation of the instrument and making the volleyball passing learning model easier to practice. According to Winarno (2011: 43) suggests that the characteristics of a good instrument have practicality in its use and are relatively easy to do.

Arifin (2009:13) explains that reliability is a series of measurements that have consistency when measurements are carried out repeatedly. According to Widoyoko (2012: 43) stated that reliability can be known through the retest 
method, namely using a test twice with a minimum time of one day. From the results of small-scale and large-scale trials that have been described previously in the research results section, Ali (2012:116) states that the level of reliability of a test is said to be high if the correlation coefficient interval is between 0.80 to 1.00. Meanwhile, according to Winarno (2011: 53) empirically the high and low reliability is indicated by a number called the reliability coefficient ranging from 0 to 1 , where the higher the reliability means the more consistent the measurement results. Agree with Arsil (2015:198) which states that the value of the reliability correlation coefficient which is included in the interval range above 0.80 can be said to have very strong or high reliability. This is also reinforced by the research of Sukirno, and Andriyanto Arlin (2017) which states that there is a significant relationship in eye and hand coordination with upper passing ability in the men's volleyball game at SMA Negeri Purwodadi. In line with the above opinion, Meirizal Usra, et al (2015) stated that weight training using pulleys had an effect on the results of the base scrutiny in volleyball games for students of SMA N 21 Palembang. Thus, research on the development of a volleyball passing over learning model for class VIII junior high school students can be accepted.

Based on the results of research and discussion on the development of training models through image media in the form of a Guide to Modification of Passing on Volleyball, it was concluded that the average of the two validators was 97\% which was categorized as very good and suitable for use in class VIII students. While the results of the trials that have been analyzed, state that the development of a volleyball passing learning model for class VIII students is very helpful for students in learning passing over more effectively.

According to Mulyana (2018), the definition of research and development or Research and Development (R\&D) is often interpreted as one of the processes or steps to develop a new product or perfect a new product or improve an existing product. always in the form of hardware (books, modules, learning aids in the laboratory class), but can also be software such as programs for data processing, 
classroom learning, libraries or laboratories.

According to Haryanti (2018: 18) images are included in the visual media that serves to channel messages from the recipient of the source to the recipient of the message. In addition, according to Rohini (2010:79) regarding the use value of images has a number of implications for teaching, namely the use of images can stimulate students' interest or attention, images are selected and adapted appropriately, helping students understand and remember the information content of accompanying verbal materials., and non-verbal terms or symbols such as arrows or other signs in the image can clarify or change the actual message.

\section{CONCLUSION}

Based on the results of research and discussion on developing an exercise model through image media in the form of a Guide to Modification of Volleyball Passing, it can be concluded that (1) The results of the validation of the development of a volleyball passing over learning model for class VIII students are validator I with a percentage of $98 \%$ and validator II with a percentage of $98 \%$. percentage $96 \%$. So, the average percentage of the two validators is $97 \%$ which is categorized as very good. This shows that the volleyball passing over learning model for class VIII students that was developed is suitable for use in class VIII students, (2) Based on the experimental results that have been analyzed, it is stated that the development of the volleyball passing over learning model for class VIII students is very helpful for students in learning to pass over more effectively. 


\section{REFERENCES}

Ali naghipour, M., Zareian, E., \& Ardakani, Z. P. (2020). The scoring technique in the final competitions of the Karate World Championships 2016. Annals of Applied Sport Science, 8(2), 1-7.

Arikunto, S. (2012). Prosedur Penelitian Suatu Pendekatan Praktik. Jakarta: Rineka Cipta.

Arsil. (2015). Evaluasi Pendidikan Jasmani dan Olahraga. Padang : Wineka Media

Azwar, Saifuddin. (2011). Reliabilitas dan Validitas. Yogyakarta: Pustaka Pelajar.

Iyakrus. Penerapan Closed Skill Dan Open Skilldalama Latihansepaktakraw Di Penjas Fkip Universitas Sriwijaya. Jurnal Volume , Nomor 1, Januari 2012.

Mulyana, D. (2018). Metodologi penelitian kualitatif (paradigma baru ilmu komunikasi dan ilmu sosial). Bandung: remaja Rosdakarya.

Sugiyono. (2013)Metode Penelitian Kuantitatif, Kualitatif dan $R \& D$. Bandung: Alfabeta.

Sukirno, dan Andriyanto Arlin. 2017. Hubungan Koordinasi Mata-Tangan Dengan Hasil Passing Atas Pada Permainan Bola Voli Putra SMA Negeri 15. Altius, Jurnal Ilmu Olahraga dan Kesehatan vol 6, N0. 1 (2017).

Suryabrata, S. (2008). Metodologi Penelitian. Jakarta : Raja Grafindo Persada.

Syafruddin. 2013. Ilmu Kepelatihan Olahraga. Padang: UNP Press Padang

Usra Meirizal, dkk. 2015. Pengaruh Latihan Beban Menggunakan Katrol Terhadap Hasil Servis Atas Dalam Permainan Bola Voli Pada Siswa Ekstrakurikuler SMA Negeri 21 Palembang. Artikel Scholar Universitas Sriwijaya.

Widoyoko, S. E.P. (2012). Teknik penyusunan instrumen Penelitian, Yogyakarta: Pustaka Pelajar

Winarno, M.E. Metodologi Penelitian Dalam Pendidikan Jasmani. Malang: Media Cakrawala Utama Press, 2011. 


\section{OLAHRAGA}

JURILL JLII KROL MURIQI.AN
Jendral A. Yani Street Lorong Gotong Royong 9/10 Ulu Palembang South Sumatera

email jurnal: jurnalhon@univpgri-palembang.ac.id situs web: http://www.univpgri-palembang.ac.id
Accredited

SINTA 3

Zaenul. (2008). Locus Of Control, Self Esteem dan Tes Baku. Bandung : Journal of Historical Studies. 